\title{
Destroyed documents: uncovering the science that Imperial Tobacco Canada sought to conceal
}

\author{
David Hammond MSc PhD, Michael Chaiton MSc, Alex Lee BSc, Neil Collishaw MA
}

Previously published at www.cmaj.ca

\section{ABSTRACT}

Background: In 1992, British American Tobacco had its Canadian affiliate, Imperial Tobacco Canada, destroy internal research documents that could expose the company to liability or embarrassment. Sixty of these destroyed documents were subsequently uncovered in British American Tobacco's files.

Methods: Legal counsel for Imperial Tobacco Canada provided a list of 60 destroyed documents to British American Tobacco. Information in this list was used to search for copies of the documents in British American Tobacco files released through court disclosure. We reviewed and summarized this information.

Results: Imperial Tobacco destroyed documents that included evidence from scientific reviews prepared by British American Tobacco's researchers, as well as 47 original research studies, 35 of which examined the biological activity and carcinogenicity of tobacco smoke. The documents also describe British American Tobacco research on cigarette modifications and toxic emissions, including the ways in which consumers adapted their smoking behaviour in response to these modifications. The documents also depict a comprehensive research program on the pharmacology of nicotine and the central role of nicotine in smoking behaviour. British American Tobacco scientists noted that "... the present scale of the tobacco industry is largely dependent on the intensity and nature of the pharmacological action of nicotine," and that "... should nicotine become less attractive to smokers, the future of the tobacco industry would become less secure."

Interpretation: The scientific evidence contained in the documents destroyed by Imperial Tobacco demonstrates that British American Tobacco had collected evidence that cigarette smoke was carcinogenic and addictive. The evidence that Imperial Tobacco sought to destroy had important implications for government regulation of tobacco. n May 8, 1998, the US State of Minnesota reached a historic settlement with the tobacco industry. ${ }^{1}$ As part of the settlement, the 7 tobacco manufacturers named in the trial were ordered to pay more than \$200 billion dollars and to make public over 40 million pages of internal tobacco industry documents. These documents have provided a wealth of information about the conduct of the tobacco industry, the health effects of smoking and the role of cigarette design in promoting addiction. ${ }^{2}$

A number of the most sensitive documents were concealed or destroyed before the trial as the threat of litigation grew. ${ }^{3,4}$ Based on advice from their lawyers, companies such as British American Tobacco instituted a policy of document destruction. ${ }^{5}$ A.G. Thomas, the head of Group Security at British American Tobacco, explained the criteria for selecting reports for destruction: "In determining whether a redundant document contains sensitive information, holders should apply the rule of thumb of whether the contents would harm or embarrass the Company or an individual if they were to be made public."

British American Tobacco's destruction policy was most rigorously pursued by its subsidiaries in the United States, Canada and Australia, likely because of the imminent threat of litigation in these countries. The policy was developed following the 1989 decision by a Canadian judge to give Canadian government representatives access to scientific research conducted by Imperial Tobacco Canada and its principal shareholder, British American Tobacco. ${ }^{7}$ This ruling prompted British American Tobacco to undertake steps to prevent scientists in its affiliate companies from retaining industry studies and to require the destruction of sensitive documents. ${ }^{8.9}$ Canadian scientists were the most resistant to this policy, ${ }^{10}$ but they too agreed to destroy their copies of British American Tobacco's scientific research. ${ }^{11}$

In a letter dated June 5, 1992, a lawyer working on behalf of Imperial Tobacco Canada informed British American Tobacco that Imperial would destroy copies of 60 documents in compliance with the document destruction policy, and he provided reference numbers for each of these documents. ${ }^{12}$ This memo was one of the earlier industry documents to be made public, and it became a key document in legal arguments about the destruction of evidence. ${ }^{13}$ The contents of the destroyed documents to which it referred, however, had never been analyzed. All that was known was that they contained

From the University of Waterloo (Hammond, Lee), Waterloo, Ont.; The University of Toronto (Chaiton), Toronto, Ont.; and Physicians for a Smoke-Free Canada (Collishaw), Ottawa, Ont

Cite as CMAJ 2009. DOI:10.1503/cmaj.080566 
what British American Tobacco considered "sensitive" research results. ${ }^{14} \mathrm{~A}$ list of the 60 documents is available in Appendix 1 (www.cmaj.ca/cgi/content/full/cmaj.080566/ DC1). Appendix 2 (www.cmaj.ca/cgi/content/full/cmaj .080566/DC1) includes summaries of 3 documents not otherwise discussed that explore the transfer of the flavouring additive coumarin to tobacco smoke..$^{15-17}$

What was the nature of the 60 reports that Imperial and British American Tobacco wanted destroyed? Although Imperial dutifully destroyed its copies of these sensitive documents, other copies of the same documents were stored at British American Tobacco headquarters in the United Kingdom and were released in 1998 through court disclosure in the Minnesota Trial and subsequent legal proceedings. ${ }^{1} \mathrm{We}$ searched British American Tobacco's archives for each of the 60 reports using the research numbers included in the original letter. ${ }^{12}$ In this article, we present the contents of these research reports.

\section{Methods}

We searched the electronic databases that contain tobacco industry documents to identify copies of the 60 destroyed research reports. The British American Tobacco Documents Archive $^{18}$ and the British American Tobacco Document Collection ${ }^{19}$ include British American Tobacco documents that were released as part of the Minnesota trial. These documents were originally housed in Guildford, England, and consist of about 7 million pages of internal reports from British American Tobacco and its subsidiaries, including Imperial Tobacco Canada and Brown \& Williamson in the US. We also searched the Health Canada and Brown \& Williamson collections using Tobacco Documents Online,,$^{20}$ and the Legacy Tobacco Documents Library, housed at the University of California at San Francisco. ${ }^{19}$ The initial search used the research numbers identified in the letter. ${ }^{12}$ Further searches were then made using a "snowball" technique that allowed us to add extra search information such as dates, authors' names and document titles to subsequent searches. Using these techniques, we identified each of the 60 reports included in the original letter. ${ }^{12}$ We retrieved, reviewed and characterized each of these reports. Information in the documents was abstracted by 3 of the authors (D.H., M.C. and A.L.). The documents were then organized into themes based on the content of each document and the collective input of all 4 authors. The scientific quality of the 47 original research reports was evaluated by the lead author (D.H.) based on the study design, methods and statistical analyses. A summary of each study, with additional detail on the methodology and results, is available in Appendix 2.

\section{Results}

All 60 documents ordered destroyed were reports of scientific work, performed either by British American Tobacco or contractors hired by British American Tobacco. The earliest report dated from 1967 and the most recent was produced in 1984. Of the 60 reports, 11 were reviews of internal research or methods development, 2 were statistical re-analyses of previous studies and the remaining 47 documents contained research findings from original studies conducted by British American Tobacco. All 47 original studies used experimental research designs, and most used advanced techniques in analytical chemistry, biological testing and animal research designs. The statistical analyses of the data were sophisticated and judged to be appropriate for the study designs, and the interpretation of the findings reflected the expertise of the industry scientists. Although the diversity of the studies contained in the documents precludes any formal evaluation of scientific quality, the research standards of the studies reported in the destroyed documents was equal to and, in many cases, exceeded the standards of peer-reviewed scientific research published during the same period. Table 1 provides a summary of the findings from key documents.

\section{Carcinogenicity and biological activity of cigarette smoke}

The destroyed documents reveal a vast body of scientific evidence on the health effects of smoking. Forty of the 60 documents pertain to carcinogenicity and "biological activity" of cigarettes. ${ }^{21-23,28-59}$ The research contained in these documents is notable both for its scope and the consistent pattern of the findings showing a link between cigarette smoke and a range of health effects. One of the reports, a 1976 review of British American Tobacco research about the biological activity of cigarette smoke, indicates that British American Tobacco had conducted research on the effects of cigarette smoke on lung cancer, bronchitis, emphysema, ciliastasis, cardiovascular disease and reproductive abnormalities, among other health effects..$^{23}$ A review of research activity at British American Tobacco's German research facilities reports an equally broad range of findings from dozens of studies. ${ }^{59}$ As one indication of the consistency of these findings, British American Tobacco scientists were surprised by studies that failed to show the carcinogenic nature of cigarette smoke. ${ }^{13}$

Many of the documents ordered destroyed were associated with Project Janus, ${ }^{22,28-35,38-58,60}$ which was a long-term research program conducted between 1965 and 1978 to determine the carcinogenic components of tobacco smoke. Tobacco condensate was applied to the skin of mice, a technique that was commonly used for determining carcinogenicity at the time. The tumorigenicity of tobacco smoke was also evaluated by use of longer-term tests exposing hamsters to mainstream cigarette smoke (smoke that is extracted through the filter end of the cigarette). ${ }^{50}$ The Janus studies concluded that long-term inhalation of tobacco smoke alone led to cancerous lesions: "The hamster inhalation and mouse skin painting systems ... do measure tumour induction by smoke. ... A number of other procedures have been shown to correlate with tumorigenicity and this appears to have relevance to lung cancer., ${ }^{23}$ Virtually all of these studies used animal models to test for carcinogenicity, although the applicability to human smokers is addressed in the reports: "In the long-term tumorigenicity tests it is assumed that similar mechanisms operate to produce the experimental tumours as are involved in human lung cancer causation. This assumption appears reasonable." ${ }^{23}$ 
Table 1: Summary of key studies from 60 documents destroyed by Imperial Tobacco Canada

\begin{tabular}{|c|c|c|}
\hline Characteristic & Study & Significance \\
\hline \multirow[t]{3}{*}{$\begin{array}{l}\text { Carcinogenicity } \\
\text { and "biological } \\
\text { activity" of } \\
\text { tobacco smoke }\end{array}$} & $\begin{array}{l}\text { Experimental } \\
\text { tumorigenesis } \\
\text { in the hamster larynx, } \\
\text { March } 1974\end{array}$ & $\begin{array}{l}\text { - An investigation of whether smoke exposure and concentration of } \\
\text { N-methyl-N-nitroso-urea (NMU) initiator had a tumorigenic effect on hamsters. } \\
\text { Exposure to cigarette smoke resulted in a } 6 \text {-fold increase in the number of } \\
\text { grade } 4 \text { laryngeal lesions, and smoke exposure had a dose-dependent effect. } \\
\text { Lesions were present even in the absence of NMU pretreatment, indicating that } \\
\text { the cigarettes were carcinogenic without an initiator. }\end{array}$ \\
\hline & $\begin{array}{l}\text { Review of biological } \\
\text { testing methods, } \\
\text { September } 1976\end{array}$ & $\begin{array}{l}\text { - A review of British American Tobacco's biological testing on the effects of } \\
\text { cigarette smoke in an effort to link biological effects with diseases such as } \\
\text { lung cancer, bronchitis, emphysema, cardiovascular disease and low infant } \\
\text { birth weight. } \\
\text { Research from } 30 \text { British American Tobacco studies was reviewed, including } \\
\text { studies of chemical smoke analysis, short-term inhalation studies with animals } \\
\text { and humans, long-term mouse skin painting tests of carcinogenicity, and } \\
\text { inhalation and reproductive studies in animals. } \\
\text { - The report highlights the advantages of using short-term in vitro tests in } \\
\text { product development. }\end{array}$ \\
\hline & $\begin{array}{l}\text { Ames mutagenic activity } \\
\text { of mainstream condensate } \\
\text { of } 6 \text { commercial } \\
\text { cigarettes, }{ }^{21} \text { October } 1984\end{array}$ & $\begin{array}{l}\text { - An investigation of mutagenic activity of existing commercial Canadian } \\
\text { cigarettes. } \\
\text { - The findings were similar with those of previous studies and showed that all of } \\
\text { the Canadian cigarettes were mutagenic. }\end{array}$ \\
\hline \multirow[t]{2}{*}{$\begin{array}{l}\text { Second-hand } \\
\text { smoke }\end{array}$} & $\begin{array}{l}\text { Pilot long-term } \\
\text { inhalation study, } \\
\text { November } 1978\end{array}$ & $\begin{array}{l}\text { - A long-term smoking study investigating changes in the lung, larynx and } \\
\text { trachea of rats exposed to smoke for a year compared to a control group. } \\
\text { - After } 52 \text { weeks, only smoke-exposed rats developed tumorigenic changes in } \\
\text { their lungs, bronchi and trachea. }\end{array}$ \\
\hline & $\begin{array}{l}\text { Investigation of } \\
\text { sidestream* }{ }^{2 m o k e} \\
\text { constituents, } \\
\text { May } 1980\end{array}$ & $\begin{array}{l}\text { - A comparison of the components of mainstream and sidestream smoke found } \\
\text { that semivolatile nitrogenous compounds (e.g., pyridines) and nicotine were } \\
\text { found to be higher in sidestream smoke. } \\
\text { The report suggests that "passive" smokers may inhale larger amounts of these } \\
\text { chemicals than smokers themselves and may be exposed to significant } \\
\text { quantities of harmful chemicals. }\end{array}$ \\
\hline \multirow[t]{2}{*}{$\begin{array}{l}\text { Nicotine } \\
\text { addiction and } \\
\text { compensation }\end{array}$} & $\begin{array}{l}\text { Preparation and } \\
\text { properties of nicotine } \\
\text { analogues, } \\
\text { November } 1972\end{array}$ & $\begin{array}{l}\text { - A report on the properties of nicotine, the addictive component of cigarettes, } \\
\text { and some of its close analogues. } \\
\text { British American Tobacco's scientists made several unsuccessful attempts to } \\
\text { synthesize nicotine analogues. }\end{array}$ \\
\hline & $\begin{array}{l}\text { Compensation for } \\
\text { changed delivery, } \\
\text { January } 1976\end{array}$ & $\begin{array}{l}\text { - A review of evidence on smoking patterns among smokers in response to } \\
\text { changes in cigarette design, including "low-nicotine" cigarettes. } \\
\text { Many smokers compensate for "lower" delivery by smoking more intensely } \\
\text { in an effort to equalize nicotine delivery. }\end{array}$ \\
\hline
\end{tabular}

*Sidestream smoke refers to the smoke that escapes primarily from the lit end of the cigarette.

\section{Relative risk between brands}

Much of the research in the destroyed documents was not simply concerned with whether tobacco smoke was carcinogenic but with testing for differences between cigarette brands. ${ }^{23,59}$ The industry was under increasing pressure from regulators and consumers to reduce the harm from smoking and sought to reduce their potential liability. The cigarettes used in Project Janus were specially produced to test the consequences of different design elements, including tobacco blend. Several destroyed documents also describe work from Project Rio, ${ }^{21,36,37}$ a multinational project that sought to rank the mutagenicity of cigarettes from around the world. Project Rio used the Ames test, a newly developed biological test that could be used to identify potential mutagens in tobacco smoke condensate. There was concern within British American Tobacco that the Ames test would be used not only to develop scientific knowledge about health effects of smoking but also as a regulatory tool by governments (e.g., to rank cigarettes similar to the rankings that already existed for nicotine or tar). ${ }^{64}$ However, the results from Project Janus and Project Rio provided discouraging results about the prospect of developing less hazardous cigarettes: all tobacco blends and types of cigarette designs were found to be carcinogenic, and most of the modifications made relatively little difference to specific carcinogenic activity. ${ }^{56-58}$ For example, in 1984, British American Tobacco tested Canadian brands such as Craven A, Players Light, duMaurier, Export A, Mark 10 and Matinée. Overall, the differences in specific mutagenic activity between brands were considered too small to be significant. ${ }^{21}$

Similar results were found in research examining the effect of filters. ${ }^{65,66}$ Filters that could selectively remove toxins from smoke without interfering with the delivery of nicotine and reducing consumer "satisfaction" have long been a primary, but elusive, goal of industry research. One of the destroyed documents reported on an experiment conducted with filters containing carbon to selectively remove vapour-phase toxins from 
cigarette smoke - a design feature that is common among current cigarette brands. ${ }^{66}$ The study found that rats exposed to the smoke filtered through carbon filters had a greater weight of particles attached to their lungs than rats exposed to less filtered smoke - the opposite of what was hypothesized. The authors reasoned that reducing some of the toxins in the vapour phase may have made the smoke less irritating, resulting in greater inhalation. The British American Tobacco scientists speculated about the implications for its consumers: "If, therefore, the human smoker shows a parallel reaction and also inhales less irritant smoke more readily, then the inferred benefit of vapour phase filters is undermined to a degree."

The conclusions from this set of studies provide critically important insights on the impact of product modifications: cigarettes that gave the appearance of reducing toxicity under biological testing have the potential to be equally or even more harmful than "conventional" cigarettes if these products also lead to increases in the intensity of smoking. This phenomenon is addressed more directly in another of the destroyed documents. David Creighton, a senior research scientist working within the commercial applications division at British American Tobacco, described the process of how smokers "compensate" for products with lower nicotine levels by increasing the amount of smoke that is inhaled. ${ }^{24}$ As Creighton explains, smokers increased their inhalation in an effort to "equalize nicotine delivery." 24

In addition to shedding light on the potential effects of selective filtration techniques such as the use of charcoal, the concept of smoker compensation was most relevant to understanding filter "ventilation" — the dominant design modification that was already being used in the 1960s and 70s to reduce the tar levels of Canadian cigarettes. British American Tobacco and Imperial Tobacco were manufacturing cigarettes with tiny "ventilation" holes positioned on the filter so that air could enter and dilute the smoke passing through the filter. However, as the report by Creighton indicates, smokers compensated by simply inhaling more smoke in order to extract a similar amount of nicotine as they would have previously inhaled from cigarettes with higher tar and nicotine levels. ${ }^{67}$

Overall, filter ventilation was an effective way for manufacturers to decrease the tar and nicotine yields of cigarettes under standard machine testing and to give the appearance of a less harmful cigarette, while continuing to deliver similar amounts to consumers. ${ }^{68}$ In fact, epidemiologic data indicates that the rise of ventilated cigarettes in Western countries coincided with an increase in the rate of adenocarcinoma, perhaps because of deeper inhalation patterns from these products.

\section{Nicotine and addiction}

Six of the destroyed documents depict a sophisticated program of research on nicotine addiction (Table 1). ${ }^{24,25,65,69-71} \mathrm{Sev}-$ eral of the destroyed reports discuss the pharmacologic action of nicotine and nicotine receptors. ${ }^{24,65,69}$ For example, Creighton speculated about a link between smoking compensation and nicotine receptors: "Since many smokers compensate for changed delivery, it has been assumed that a feedback mechanism exists to let the smoker know whether to take more or less smoke from a particular brand. This implies the presence of a nicotine sensitive receptor." ${ }^{24}$ British American Tobacco scientists recognized at this early stage that research on nicotine receptors represented both an opportunity for the company and a serious threat: "... the present scale of the tobacco industry is largely dependent on the intensity and nature of the pharmacologic action of nicotine." "Should nicotine become less attractive to smokers, the future of the tobacco industry would become less secure." ${ }^{69}$ To anticipate the threat from the pharmaceutical industry or "antitobacco" groups, British American Tobacco conducted research into nicotine antagonists - chemicals that could block nicotine receptors and essentially neutralize the effect of nicotine in cigarette smoke. Report Rd. 953 states: "If such a compound were included in a product competitive to tobacco, it might negate the effect of nicotine and lead to the rejection of the smoking habit by some consumers." ${ }^{69}$ The report concluded that research was needed on antagonists to prevent such "... a future assault on the industry." ${ }^{69}$

Collectively, these research reports include convincing evidence about the addictive nature of nicotine - a fact that was vehemently challenged at the time in public by British American Tobacco and Imperial Tobacco Canada. For example, a 1984 report from C.I. Ayres, a British American Tobacco scientist, was "designed to identify and characterise how nicotine derived from cigarette smoke can interact with the body, and in particular the active centres of the brain. This specific interaction is believed to form an essential element of a smoker's satisfaction. ... Taken together, the evidence suggests that self-administration of nicotine may be the primary motivation for smoking." ${ }^{25}$ This document suggests that the primary emphasis of British American Tobacco research was not simply to document the addictive nature of nicotine in cigarette smoke but to pursue commercial applications for facilitating nicotine addiction under different conditions: "The general programme of study is intended to develop our understanding of the pharmacologic role of nicotine within the context of human smoking behaviour. ... The findings will be used as appropriate in the process of developing lower delivery products with full smoking characteristics." 25

\section{Second-hand smoke}

Eleven of the destroyed documents included original research findings on the effects of second-hand smoke. ${ }^{26,27,72-80}$ Nine of studies were experiments performed on rats to determine the effects of second-hand and mainstream smoke. ${ }^{26,27,73-79}$ The primary outcome of the tests was the finding that "In all exposed animals there was a consistent smoke-induced change in the larynx ... change was quantifiable and related to the length of exposure." 74 These experiments were not long-term assays like the mouse skin-painting tests, which could take years to complete; rather, the rat inhalation tests sometimes reached their "endpoint" in as little as 2-8 weeks depending on the experiment. One test even showed that significant results could be obtained without requiring the scientists to come in on the weekend to expose the rats to smoke. ${ }^{73}$ For example, the first study in this series of studies tested the effect of second-hand smoke on rat lungs. ${ }^{74}$ Rats were exposed to a set amount of smoke 4 times a day for 1 to 2 weeks; after 2 
weeks, hyperplasia and metaplasia in the cells of rat lungs were observed even among rats that were only exposed for 40 minutes $(4 \times 10$ minutes $)$ per day.

Another study investigated second-hand smoke by testing the constituents from sidestream smoke - the smoke that escapes primarily from the lit end of the cigarette. ${ }^{75}$ The scientists concluded that second-hand smoke was in fact more toxic than mainstream smoke. "Especially for low delivery cigarettes, this suggests that it is the 'passive smoker' who obtains the larger amounts of these components, albeit in a diluted form, rather than the smoker himself." 72 The risks of second-hand smoke and the prospect of eventual regulation were sufficiently clear that British American Tobacco scientists began investigating technologies to clear ambient smoke from indoor areas. For example, Project Rd. 1922 examined the effectiveness of air ionizers; however, the study found that the clearance effects were "relatively small" and unlikely to be any more effective than opening a window. ${ }^{80}$

\section{Scientific quality}

The documents that Imperial Tobacco sought to destroy characterized a sophisticated research program into the health effects of tobacco products, second-hand smoke and addiction. The scientific quality of the research reports either met or exceeded contemporary standards in terms of study design, methods and statistical analyses. All 47 original research studies used experimental designs and most used advanced techniques in analytical chemistry, biological testing and animal research designs. The studies are notable both for the wide range of research designs used to examine the health effects of smoking and for the consistency of the findings. The diversity of research designs reported in the documents also served different purposes: whereas animal models allowed for stronger causal inferences about the carcinogenicity of cigarette smoke, biological testing provided a more efficient means of testing individual products. Meanwhile, studies involving humans highlighted the implications of product modifications for smoking behaviour and consumer exposure. The statistical analysis of these data was sophisticated and the interpretation of the findings reflects the expertise of the industry scientists. Overall, the scientific quality and the scope of this evidence was likely an important factor in the decision to target these documents for destruction.

\section{Discussion}

In 1954, the Canadian Medical Association issued its first public warnings about the risks of smoking, followed in 1963 by the landmark statement in the House of Commons from Canada's Minister of National Health and Welfare that smoking was harmful to health. Despite these historic proclamations, there remained considerable uncertainty about the extent of the health risks, whether some products were less harmful than others, and what government measures should be taken to reduce the harm from tobacco. During this period, British American Tobacco and Imperial Tobacco Canada collected high-quality scientific evidence that bore directly on these issues and had the potential to hasten effective public health regulation. However, British American Tobacco and Imperial Tobacco concealed this information and argued that there was a lack of evidence to support government measures such as workplace smoking restrictions and mandatory health warnings on packages. ${ }^{81}$ For example, in 1990, the president of the Canadian Tobacco Manufacturers' Council submitted a written objection to government proposals for a new health warning on the risks of second-hand smoke, stating that "we do not accept that there is any credible or reliable evidence to establish that environmental tobacco smoke (ETS) constitutes a genuine health hazards to smokers." 82 The destroyed documents indicate that this evidence had already been collected by the industry and was concealed in confidential files.

Efforts to conceal research findings on "low-tar" cigarettes have been particularly damaging to health policy and government regulation. Canadian manufacturers began producing and marketing "lower-tar" cigarettes during the 1960s and 70 s as a direct response to growing health concerns among consumers. ${ }^{81}$ Without the benefit of independent evidence on the potential benefits of "lower-tar" cigarettes, many leading health agencies supported this industry strategy. ${ }^{83}$ For example, in the 1970s, Health and Welfare officials urged the Canadian manufacturers to reduce tar levels further and to print tar numbers on packages to help guide consumers. ${ }^{81}$ The destroyed documents indicate that British American Tobacco had collected evidence that cast doubt on the potential health benefits of "low-delivery" products. In vivo studies indicated that human smokers were compensating for "low-tar" cigarettes by smoking them more intensely, while biological testing from Projects Janus and Rio revealed negligible differences in the carcinogenity and mutagenicity of cigarette brands. Without access to this evidence, several decades elapsed before regulators and health agencies reached consensus that "low-tar" products did not reduce risk. ${ }^{81,84}$ In the meantime, millions of smokers switched to these brands, many under the assumption of reduced harm as an alternative to quitting. ${ }^{84}$ The legacy of low-tar cigarettes continues today: most Canadian smokers continue to believe that lower-tar cigarettes are less harmful, and misleading tar numbers continue to be printed on Canadian packages. ${ }^{85}$ Furthermore, many governments and health agencies have yet to abandon the intuitive, but misguided, position that there are public health benefits to further tar reductions. For example, the Canadian Medical Association continues to recommend that "the federal government set ceilings on the content of toxic ingredients such as tar ... and lower these ceilings progressively." 86 Had the tobacco industry been forthcoming about the evidence collected about human smoking behaviour and low-tar cigarettes, much of the confusion over these products may have been averted.

Imperial Tobacco's attempt to destroy the evidence in the 60 documents is consistent with the tobacco industry's welldocumented efforts to undermine science on the risks of smoking and to engineer doubt in the minds of health professionals and consumers. ${ }^{87}$ Imperial Tobacco Canada and British American Tobacco publicly denied the importance of the health effects that were clearly shown in the 60 destroyed documents. For example, in 1987 - 9 years after the conclu- 
sion of Project Janus, which showed the carcinogenicity of tobacco smoke - the chairman of Imperial Tobacco Canada and the chair of the Canadian Tobacco Manufacturers Council, Jean-Louis Mercier, testified in front of a House of Commons Legislative Committee, stating that "It is not the position of the industry that tobacco causes any disease. ... The role, if any, that tobacco or smoking plays in the initiation and the development of these diseases is still very uncertain." ${ }^{88}$ Further, in 1996, Martin Broughton, the chief executive of British American Tobacco stated, "We have not concealed, we do not conceal and we will never conceal. ... we have no internal research which proves that smoking causes lung cancer or other diseases or, indeed, that smoking is addictive." 89

Finally, the destruction of documents by Imperial Tobacco Canada has direct implications for industry liability and new litigation that is proceeding in Canada. Canadian courts are currently being asked to consider whether the tobacco industry should be liable for the health care costs attributable to smoking. In the first Canadian trial of its kind, the province of British Columbia has launched health care cost-recovery litigation, claiming that the tobacco companies were part of a conspiracy that engaged in wrongs leading to massive health care costs. In September 2005, the Supreme Court unanimously ruled that parent companies - including British American Tobacco can be cited as defendants and may be found liable. The case is currently proceeding to trial. Seven other provinces have amended their legislation to allow for similar cost-recovery lawsuits, including New Brunswick and Ontario, which have initiated legal action. Ontario recently announced that it is seeking $\$ 50$ billion in damages for past and ongoing health-care costs linked to tobacco-related illness. Tobacco companies have yet to pay any compensation either to the Canadian government or to their consumers as a result of their actions.

\section{This article has been peer reviewed.}

Competing interests: David Hammond has been retained as an expert witness for the federal government in litigation related to the tobacco industry. $\mathrm{He}$ received an honorarium from Physicians for a Smoke-Free Canada to help conduct the background research for this article and to prepare it for publication. Michael Chaiton was employed by Physicians for a Smoke-Free Canada during the drafting of this article. He is currently employed by the Ontario Tobacco Research Unit. None declared for Alex Lee and Neil Collishaw.

Contributors: Neil Collishaw was responsible for the conception of this article. All of the authors made substantial contributions to the design, analysis, writing and revision of the article, and approved the final version submitted for publication.

Acknowledgements: This research was funded by a Policy Research Grant from the Canadian Tobacco Control Research Initiative with support from the Centre for Behavioural Research and Program Evaluation, National Cancer Institute of Canada, Canadian Cancer Society. We thank Cynthia Callard, Executive Director, Physicians for a Smoke-Free Canada, for researching and assembling documents vital to the completion of this article.

\section{REFERENCES}

1. State of Minnesota. Tobacco documents: Judge Fitzpatrick's order. (November 1, 1995). County of Ramsey, District Court, Second Judicial District, File \# C1-948565. Available: www.rkmc.com/Tobacco_Documents_Judge_Fitzpatricks_Order _November_1_1995.htm (accessed 2009 Aug. 13).

2. Hurt RD, Robertson CR. Prying open the door to the tobacco industry's secrets about nicotine. JAMA 1998;280:1173-81.
3. Hanauer P, Slade J, Barnes DE, et al. Lawyer control of internal scientific research to protect against products liability lawsuits: The Brown and Williamson documents. JAMA 1995;274:234-40.

4. Liberman J. The shredding of BAT's defense: McCabe v. British American Tobacco Australia. Tob Control 2002;11:271-4.

5. Heard AL. Co-ordination of group R\&D visit to Imperial Tobacco Canada 21st22nd June, 1990. Bates: 401103335-401103338. Available: http://bat.library .ucsf.edu/data/f/i/h/fih40a99/fih40a99.pdf (accessed 2009 Aug. 13)

6. Thomas AG. Destruction of classified documents. Bates: 602828740. Available: http://bat.library.ucsf.edu/data/a/o/f/aof50a99/aof50a99.pdf (accessed 2009 Aug. 13).

7. Ackman RS. Letter from Roger S. Ackman to Stuart Chalfen regarding order to produce documents. Montréal (QC): Imperial Tobacco; 1989. Bates: 202339918. Available: http://bat.library.ucsf.edu/data/l/t/q/ltq26a99/ltq26a99.pdf (accessed 2009 Aug. 13)

8. Cannar NB. Note from Nick Cannar to SP Chalfen regarding meeting. London (UK): British American Tobacco; 1990. Bates: 202347084. Available: http://bat .library.ucsf.edu/tid/ifr06a99 (accessed 2009 Aug. 13).

9. Cannar NB. Research documents: agenda. London (UK): British American Tobacco; 1990. Bates: 202347085. Available: http://bat.library.ucsf.edu/tid /nod73a99 (accessed 2009 Aug. 13).

10. Cannar NB. Note for Mr. S.P. Chalfen: Documents in Canada. London (UK): British American Tobacco; 1990. Bates: 202313481. Available: http://bat.library .ucsf.edu/tid/nml11a99 (accessed 2009 Aug. 13).

11. Cannar NB. Note for Mr. S.P. Chalfen: Document retention policy. London (UK): British American Tobacco; 1990. Bates: 202313482-202313483: Available: http://bat.library.ucsf.edu/tid/oml11a99 (accessed 2009 Aug. 13).

12. Potter S. Letter: Imperial Tobacco Limited. Montréal (QC): Ogilvy Renault; 1992 Bates: 202313423-202313425. Available: http://bat.library.ucsf.edu/data/u/l/1 /ull11a99/ull11a99.pdf (accessed 2009 Aug. 13)n

13. McCabe v. British American Tobacco Australia (2002), no. 8121. N.G. VSC 73, (Melbourne, Aust.) Eames J. Available: http://old.ash.org.uk/html/conduct/pdfs /mccabejudgement.pdf (accessed 2009 Aug. 13).

14. Meltzer J. Note from John Meltzer to Stuart P. Chalfen regarding an attached letter from Ogilvy Renault. London (UK): Lovell, White, Durrant; 1992. Bates: 202313418-421. Available: http://bat.library.ucsf.edu/data/t/1/1/t1111a99 /tll11a99.pdf (accessed 2009 Aug. 13).

15. Evelyn $\mathrm{S}$. The transfer of flavouring materials part I: coumarian from pipe tobacco Report no. Rd. 391-R. Southampton (UK): Group Research and Development Centre, British American Tobacco Company Limited; 1966. Bates: 504001372/1386. Available: http://legacy.library.ucsf.edu/tid/ovp10f00 (accessed 2009 Aug. 13).

16. Evelyn S. The transfer of flavouring materials part II: 6-methylcoumarin from pipe tobacco. Southampton (UK): Group Research and Development Centre, British American Tobacco Company Limited; 1966. Bates: 105444420-105444435. Available: http://legacy.library.ucsf.edu/tid/khe54a99 (accessed 2009 Aug. 13).

17. Evelyn S, Felton D. The transfer of coumarin part IIII: The transfer from pipes and cigarettes under various smoking conditions and the retention of coumarin by smokers. Report no. Rd.505-R. Southampton (UK): Group Research and Development Centre, British American Tobacco Company Limited; 1967. Bates: 504001337/1371. Available: http://legacy.library.ucsf.edu/tid/nvp10f00 (accessed 2009 Aug. 13).

18. British American Tobacco Documents Archive. San Francisco (CA): University of California San Francisco; 2004. Available: http://bat.library.ucsf.edu/ (accessed 2009 Aug. 13).

19. Legacy Tobacco Documents Library. San Francisco (CA): University of California, San Francisco, 2007. Available: http://library.ucsf.edu/tobacco/batco/ (accessed 2009 Aug. 13).

20. Tobaccodocuments.org. Tobacco Documents Online; 2009. Available: www.tobaccodocuments.org/ (accessed 2009 Aug. 13).

21. Massey E. Ames mutagenic activity of mainstream condensate of six commercial cigarettes for Imperial Tobacco Ltd (Canada). Project Rio: report no. T153-C, restricted. British American Tobacco Limited; 1984. Bates: 105487577-7599. Available: http://legacy.library.ucsf.edu/tid/gft67a99/pdf (accessed 2009 Sept. 9).

22. Karbe E, Kiendl J, Konigsmann G, et al. Carcinogenicity of smoke condensate to mouse skin: experiment B2. Frankfurt (Germany): Battelle; 1973. Bates: 650027836-650027941. Available: http://legacy.library.ucsf.edu/tid/ony14f00 (accessed 2009 Aug. 13).

23. Bass DW. Review of biological testing methods: report no. T.90, September 1976 Bates: 402386081-102. Available: http://bat.library.ucsf.edu/data/f/v/c /fvc54a99/fvc54a99.pdf (accessed 2009 Aug. 13).

24. Creighton D. Compensation for changed delivery. Report no. Rd. 1300. Restricted. Southampton (UK): Group Research and Development Centre, British American Tobacco Company Limited; 1976. Bates: 650008449/8480. Available: http://legacy.library.ucsf.edu/tid/oky14f00 (accessed 2009 Aug. 13).

25. Ayres CI, Templeton WW. Receptors for nicotine in the central nervous system: I radio ligand binding studies. Report no. Rd. 1960 restricted. Southampton (UK): Group Research and Development Centre, British American Tobacco Company Limited 1984. Bates: 650371230-650371265. Available: http://tobaccodocuments org/bw/79707.html (accessed 2009 Aug. 13).

26. Anderson I, Binns R, Lugton W. Distribution of inhaled smoke particles in the rat lung. Report no. Rd. 1566 restricted. Southampton (UK): Group Research and Development Centre, British American Tobacco Company Limited; 1978. Bates: 650010411/0431. Available: http://legacy.library.ucsf.edu/tid/gjs00f00 (accessed 2009 Aug. 13).

27. Smith G. Pilot long-term inhalation study (interim report). Report no. Rd. 1633 restricted. Southampton (UK): Group Research and Development Centre, British American Tobacco Company Limited; 1978. Bates: 650016778-650016797. 
Available: http://tobaccodocuments.org/bw/17749.html (accessed 2009 Aug. 13).

28. Chakraborty BB, Thornton RE. Analysis of Janus condensate solutions. Report no. Rd. 808-R 710729. Southampton (UK): Group Research and Development Establishment, British American Tobacco Company Limited; 1995. Bates: 657006561-657006590. Available: http://tobaccodocuments.org/bw/11921576.html (accessed 2009 Aug. 13).

29. Wilkes EB. The first promotion test. Report no. Rd. 872-R. Southampton (UK): Group Research and Development Center, British American Tobacco Company Limited; 1972. Bates: 650011164-650011182. Available: http://tobaccodocuments .org/bw/17553.html (accessed 2009 Aug. 13).

30. Wilkes EB. The statistical analysis of an experiment to compare the tumourpromoting activity of the condensate from the cigarettes used in the Janus long-term test B11. [appendix to report B35]. Frankfurt (Germany): Battelle; 1976. Bates: 100997280-100997291. Available: http://bat.library.ucsf.edu/tid/ncg34a99 (accessed 2009 Aug. 13).

31. Wilkes EB. A statistical analysis of the incidence of tumour-bearing animals in Janus experiments B6/B7 (Calibration Groups). [appendix to report B34]. Frankfurt (Germany): Battelle; 1976. Bates: 650028385-8400. Available: http://legacy .library.ucsf.edu/tid/bas00f00 (accessed 2009 Jul. 3)

32. Wilkes EB. A statistical analysis of the incidence of tumour-bearing animals in Janus Experiment B8. Report no. Rd. 1352. London (UK): British American Tobacco Company Limited; 1976. Bates: 105473470-105473582. Available: http://bat.library.ucsf.edu/tid/phc34a99 (accessed 2009 Aug. 13).

33. Wilkes EB. Appendix A: Statistical analysis of the incidence of tumour-bearing animals in Janus Experiment B9, report no. Rd. 1481 restricted. Frankfurt (Germany): Battelle; 1977. Bates: 650030006-650030082. Available: http://tobaccodocuments .org/bw/18127.html (accessed 2009 Aug. 13).

34. Wilkes EB. A statistical analysis of the incidence of tumour-bearing animals in Janus promotion study B30/31, report no. Rd. 1517 restricted. Southampton (UK): Group Research and Development Centre, British American Tobacco Company Limited; 1977. Bates: 650029361-650029407. Available: http://tobaccodocuments .org/bw/18117.html (accessed 2009 Aug. 13).

35. Wilkes E. A comparison of the tumorigenic activities of Janus condensates B0, B2 and B4. Southampton (UK): Group Research and Development Centre, British American Tobacco Company Limited; 1977. Bates: 504001185-504001277. Available: http://legacy.library.ucsf.edu/tid/ijd72d00 (accessed 2009 Aug. 13)

36. Barnes A, Massey E. Ames mutagenic activity of sidestream condensate of eight commercial cigarettes from the Finnish market. Report no. T.169. Southampton (UK) Group Research and Development Centre, British American Tobacco Company Limited; 1987. Bates: 570216221-570216233. Available: http://tobaccodocuments .org/bw/949798.html (accessed 2009 Aug. 13).

37. Massey E, Barnes A. Ames mutagenic activity of sidestream condensate. Comparison of prototype slim cigarettes \& six commercial cigarettes from the Swiss market. Report no. T.172. Southampton (UK): Group Research and Development Centre, British American Tobacco Company Limited; 1987. Bates: 570216191-570216204. Available: http://tobaccodocuments.org/bw/949796.html (accessed 2009 Aug. 13).

38. Ayres CI. Long-term skin-painting experiments progress report: July 1967. Report no. B-8. London (UK): British American Tobacco Company; 1967. Bates: 105548245 105548316. Available: http://bat.library.ucsf.edu/tid//zl34a99 (accessed 2009 Aug. 13)

39. Wilkes EB. The tumorigenic index. London (UK): British American Tobacco Company; 1968. Bates: 402397893-402397921. Available: http://bat.library ucsf.edu/tid/kvc54a99 (accessed 2009 Aug. 13).

40. Karbe E. The promotion activity of tobacco smoke condensates to mouse skin B91 and B9-6 cigarettes. Frankfurt (Germany): Battelle; 1971. Bates: 100997205 100997257. Available: http://bat.library.ucsf.edu/tid/mcg34a99 (accessed 2009 Aug. 13).

41. Karbe E, Kiendl J, Königmann G, et al. Carcinogenicity of smoke condensate to mouse skin: experiment B0. Frankfurt (Germany): Battelle; 1972. Bates: 100996922-100997080. Available: http://bat.library.ucsf.edu/tid/xyr24a99 (accessed 2009 Aug. 13).

42. Karbe E. The promotion activity of tobacco smoke condensates to mouse skin: cigarettes B9-2, B9-3, B9-4 and B9-5. Frankfurt (Germany): Battelle; 1972. Bates 103382587-103382622. Available: http://bat.library.ucsf.edu/tid/hbt85a99 (accessed 2009 Aug. 13)

43. Kramer H, Karbe E, Kiendl J, et al. Carcinogenicity smoke condensate to mouse skin experiment B1. Frankfurt (Germany): Battelle; 1972. Bates: 402434943-402435056. Available: http://bat.library.ucsf.edu/tid/bqy74a99 (accessed 2009 Aug. 13)

44. Karbe E, Koster K. Experimental tumorigenesis in the hamster larynx. The promoting activity of inhaled smoke from cigarette BO. Frankfurt (Germany): Battelle; 1974. Bates: 100462460-100462485. Available: http://bat.library.ucsf.edu /tid/aun24a99 (accessed 2009 Aug. 13).

45. Karbe E, Kiendl J, Konigsmann G, et al. Carcinogenicity of smoke condensate to mouse skin: experiment B3. Frankfurt (Germany): Battelle; 1974. Bates 650029662-650029757. Available: http://legacy.library.ucsf.edu/tid/apv23f00 (accessed 2009 Aug. 13)

46. Karbe E, Klendl J, Konigsmann G, et al. Carcinogenicity of smoke condensate to mouse skin: experiment B4. Frankfurt (Germany): Battelle; 1974. Bates 682638630-682638730. Available: http://legacy.library.ucsf.edu/tid/gbp90f00 (accessed 2009 Aug. 13)

47. Kramer H, Karbe E, Kiendl J, et al. Carcinogenicity of smoke condensate to mouse skin: experiment B5. Frankfurt (Germany): Battelle; 1975. Bates: 402434117 402434212. Available: http://bat.library.ucsf.edu/tid/wqy74a99 (accessed 2009 Aug. 13)

48. Karbe E, Kiendl J, Konigsmann G, et al. Carcinogenicity of smoke condensate to mouse skin: experiments B6 and B7. Frankfurt (Germany): Battelle; 1976. Bates:
650028062-650028231. Available: http://tobaccodocuments.org/bw/18091.html (accessed 2009 Aug. 13).

49. Karbe E, Konigsmann G. The promotion activity of tobacco smoke condensate to mouse skin: cigarettes B11/1, B11/2 and B11/3. Frankfurt (Germany): Battelle; 1976. Bates: 100997258-100997291. Available: http://legacy.library.ucsf .edu/tid/ncg34a99 (accessed 2009 Aug. 13).

50. Karbe E, Koster K, Gwiessner S, et al. Experimental tumorigenesis in the hamster larynx. The activity of inhaled smoke from cigarette B 12/1 and B12/2. Frankfurt (Germany): Battelle; 1976. Bates: 100997258-100997291. Available: http://legacy.library.ucsf.edu/tid/mcy14f00/pdf (accessed 2009 Sept. 9)

51. Walker D, Jackson M. A study on the tumour-promoting activity of tobacco smoke condensates applied to mouse skin: cigarettes B13/1- 8. Wickham (UK): Wickham Research Laboratories; 1976. Bates: 1193.01. Available: http://legacy library.ucsf.edu/tid/xdd72d00 (accessed 2009 Aug. 13).

52. Gwiebner S, Karbe E, Koster K, et al. Experimental tumorigenesis in the hamster larynx: the effect of inhaled smoke from cigarette B0 on vitamin-A deficient animals Frankfurt (Germany): Battelle; 1976. Bates: 650029408/9441. Available: http://legacy library.ucsf.edu/tid/hoy14f00 (accessed 2009 Aug. 13).

53. Karbe E, Kiendl J, Königsmann G, et al. Carcinogenicity of smoke condensate to mouse skin: experiment B8. Frankfurt (Germany): Battelle; 1977. Bates: 402446738-402446899. Available: http://bat.library.ucsf.edu/tid/upm74a99 (accessed 2009 Aug. 13).

54. Karbe E, Preub W, Wilkes E. The promotion activity of tobacco smoke condensate to mouse skin, dose dependence and interaction of Dmba B9/1 and B9/6 condensates. Frankfurt (Germany): Battelle; 1977. Bates: 1159.01. Available: http://legacy .library.ucsf.edu/tid/gjd72d00 (accessed 2009 Aug. 13).

55. Jackson MC, Walker D. A study on the tumour promoting activity of tobacco smoke condensates applied to mouse skin: cigarettes B32/1-6. Wickham (UK) Wickham Research Laboratories;1977. Bates: 650027421-650027476. Available: http://tobaccodocuments.org/bw/18080.html (accessed 2009 Aug. 13).

56. Chudzinski R, Karbe E, Kiendl J, et al. Carcinogenicity of smoke condensate to mouse skin: experiment B9. Frankfurt (Germany): Battelle; 1977. Bates: 650029758/9919. Available: http://legacy.library.ucsf.edu/tid/las00f00 (accessed 2009 Aug. 13).

57. Karbe E, Kiendl J, Konigsmann G. Carcinogenicity of smoke condensate to mouse skin: experiment B 10. Frankfurt (Germany): Battelle; 1978. Bates: 650028649 650028708. Available: http://tobaccodocuments.org/bw/18101.html (accessed 2009 Aug. 13)

58. Karbe E, Kiendf J, Konlgsmann G. Carcinogenicity of smoke condensate to mouse skin: experiment B 11. Frankfurt (Germany): Battelle; 1978. Bates 650028820650028868. Available: http://tobaccodocuments.org/bw/18106.html (accessed 2009 Aug. 13).

59. Biological activity of cigarette smoke and condensate: results of biological investigations [transalation from German]. FE Report no. 261. Bates: 402381098-402381126. Available: http://bat.library.ucsf.edu/data/b/p/p/bpp84a99/bpp84a99.pdf (accessed 2009 Aug. 13)

60. Wilkes EB. The design and analysis of an experiment to compare the tumour-promoting activities of the condensates from cigarettes D184 to D189 inclusive. Report no. Rd. 1198-R. Southampton (UK): Group Research and Development Centre. British American Tobacco Limited; 1975. Bates: 105437930-105437968. Available: http://legacy.library.ucsf.edu/tid/wci57a99/pdf (accessed 2009 Sept. 7).

61. Backhurst JD, Creighton DE, Dymond $\mathrm{H}$, et al. Retention of nitric oxide in the human respiratory system. Report no. Rd. 828-R 710921. Southampton (UK): Group Research and Development Establishment, British American Tobacco Company Limited; 1971. Bates: 650003248-650003261. Available: http://tobaccodocuments .org/bw/17273.html (accessed 2009 Aug. 13).

62. Baker RR. A review of the genetics and consequences of alpha 1-antitrypsin deficiency. Report no. Rd. 1394-U, unclassified. Southampton (UK): Group Research and Development Centre, British American Tobacco Company Limited; 1976. Bates: 650008596/8631. Available: http://legacy.library.ucsf.edu/tid/ghs00f00/ (accessed 2009 Aug. 13).

63. Baker RR. A review of the genetics and consequences of alpha 1-antitrypsin deficiency. Report no. Rd. 1394-A, unclassified. London (UK): British American Tobacco Company Limited; 1977. Bates: 105472197-105472255. Available: http://legacy.library.ucsf.edu/tid/mhc34a99/ (accessed 2009 Aug. 13).

64. Biological Conference, Southampton; 1984 Apr. 9-11. Southampton (UK): Group Research and Development Centre, British American Tobacco Company Limited; 1984. Bates: 401035491-5494. Available: http://bat.library.ucsf.edu/data/z/k/z /zkz80a99/zkz80a99.pdf (accessed 2009 Aug. 13).

65. Horsewell HG, Phelpstead J. Triple filters containing mixed adsorbents. Report no. Rd. 1632. Southampton (UK): Group Research and Development Centre, British American Tobacco Company Limited; 1978. Bates: 650322793-650322818. Available: http://tobaccodocuments.org/bw/70208.html (accessed 2009 Aug. 13).

66. Prowse R, Read G, Smith G. A comparative inhalation study on smoke from cigarettes with different filters. Report no. Rd. 1729-C. Southampton (UK): Group Research and Development Centre, British American Tobacco Company Limited; 1980. Bates: 650031977-650032025. Available: http://tobaccodocuments org/bw/585032.html (accessed 2009 Aug. 13)

67. Hammond D, Collishaw N, Callard C. Tobacco industry research on smoking behaviour and product design. Lancet 2006;367:781-7.

68. US Department of Health and Human Services. Risks associated with smoking cigarettes with low machine measured yields of tar and nicotine. Bethesda (MD): US Department of Health and Human Services, Public Health Services, National Institutes of Health; National Cancer Institute, 2001.

69. Kilburn KD, Underwood JG. Preparation and properties of nicotine analogues 
report no. Rd. 953-R. Southampton (UK): Group Research and Development Centre, British American Tobacco Company Limited; 1972. Bates: 650014564/4619. Available: http://legacy.library.ucsf.edu/tid/qly14f00 (accessed 2009 Aug. 13).

70. Massey S. Examination of a concept proposed by Gori for rating cigarettes. Southampton (UK): Group Research and Development Centre, British American Tobacco Company Limited; 1981. Bates: 105582425-105582457. Available: http://legacy.library.ucsf.edu/tid/gib34a99 (accessed 2009 Aug. 13).

71. Creighton D. Dr. MAH Russell's "safer cigarettes" study. Report no. RD 1652. Southampton (UK): Group Research and Development Centre, British American Tobacco Company Limited; 1979. Bates: 105517627-105517659. Available: http://legacy.library.ucsf.edu/tid/uhc34a99 (accessed 2009 Aug. 13).

72. Greig CC, Hook RG. Investigation of sidestream smoke constituents from four tobacco types. Report no. Rd. 1734. Southampton (UK): Group Research and Development Centre, British American Tobacco Company Limited; 1980. Bates: 650331049/1077b. Available: http://legacy.library.ucsf.edu/tid/dun23f00/ (accessed 2009 Aug. 13).

73. Binns R, Smith G, Wilton LV. Changes in the respiratory tract of rats exposed to smoke for 5 or 7 days per week for 6 weeks. Report no. Rd. 1519. 1977. Bates: 650015088-650015111. Available: http://legacy.library.ucsf.edu/tid/uly14f00/pdf (accessed 2009 Sept. 9).

74. Smith G. Scanning electron microscope study of the response of the larynx and trachea of the rat to smoke exposure. Report no. Rd. 1552 Restricted. Southampton (UK): Group Research and Development Centre, British American Tobacco Company Limited; 1977. Bates: 650020970-650020986. Available: http://tobaccodocuments .org/bw/17889.html (accessed 2009 Aug. 13).

75. Smith G. Response of the rat larynx and trachea to smoke during smoke acclimatisation period. Report no. Rd. 1553 restricted. Southampton (UK): Group Research and Development Centre, British American Tobacco Company Limited; 1977. Bates: 650020987/1005. Available: http://legacy.library.ucsf.edu/tid/cny14f00 (accessed 2009 Aug. 13).

76. Read GA. Studies on mucus production (first report). Report no. Rd. 1589 restricted. Southampton (UK): Group Research and Development Centre, British American Tobacco Company Limited; 1978. Bates: 650010299/0319. Available: http://legacy.library.ucsf.edu/tid/dly14f00 (accessed 2009 Aug. 13).

77. Read GA. Acute physiological and biochemical measurements in response to whole smoke, vapour phase and pure CO exposure. Report no. Rd. 1640 restricted. Southampton (UK): Group Research and Development Centre, British American Tobacco Company Limited; 1978. Bates: 650016650-650016687. Available: http://tobaccodocuments.org/bw/17745.html (accessed 2009 Aug. 13).

78. Beven JL, Smith G, Wilton LV. An exposure system for the bioassay of inhaled sidestream cigarette smoke. Report no. Rd. 1747-C restricted. Southampton (UK): Group Research and Development Centre, British American Tobacco Company
Limited; 1980. Bates: 650031882-650031902. Available: http://tobaccodocuments .org/bw/18168.html (accessed 2009 Aug. 13).

79. Beven JL, Smith G. Characterisation of the conditions necessary for a sidestream smoke inhalation bioassay. Report no. Rd. 1921 restricted. Southampton (UK): Group Research and Development Centre, British American Tobacco Company Limited; 1983. Bates: 650000338-650000368. Available: http://tobaccodocuments .org/bw/17187.html (accessed 2009 Aug. 13).

80. Ayres CI, Read GA, Richardson RB, et al. The way in which air ionizers reduce the density of smoke in a closed environment. Report no. Rd. 1922830517 Southampton (UK): Group Research and Development Centre, British American Tobacco Company Limited; 1983. Bates: 650349539-650349586. Available: http://tobaccodocuments.org/bw/78578.html (accessed 2009 Aug. 13).

81. Cunningham R. Smoke \& mirrors: The Canadian tobacco war. Ottawa (ON): Inter national Development Research; 1996.

82. Neville WH. Letter to the Chief Legislative and Regulatory Processes, Environmental Health Directorate. Health and Welfare Canada, 1990.

83. Fairchild A, Colgrove J. Out of the ashes: the life, death, and rebirth of the "safer" cigarette in the United States. Am J Public Health 2004:94:192-204.

84. Burns DR, Major JM, Shanks TG, et al. Smoking lower yield cigarettes and disease risks. In: Shopland DR, Burns DM, Benowitz NI, et al, editors. Risks associated with smoking cigarettes with low machine-measured yields of tar and nicotine. Bethesda (MD): US National Institutes of Health, National Cancer Institute; 2001. p. 65-158.

85. Health Canada. Toxics information on cigarette packaging: results of a survey of smokers. Toronto (ON): Environics Research Group; 2003. Available: http://www tobaccolabels.ca/constitu/canada (accessed 2009 Aug. 13).

86. Canadian Medical Association. CMA Policy: Tobacco control (update 2008). Ottawa (ON): The Association; 2008. Available: http://policybase.cma.ca/dbtwwpd/Policypdf/PD08-08.pdf (accessed 2009 Aug. 13).

87. Diethelm PA, Rielle JC, McKee M. The whole truth and nothing but the truth? The research that Philip Morris did not want you to see. Lancet 2005;366:86-92.

88. Mercier JM. Minutes of Proceedings and Evidence of the Legislative Committee on Bill C-204. AG-142A, 3:22. p. 24402. Ottawa (ON): House of Commons, 1987.

89. Proctor C. BAT industries — Smoking gun? Observer [London]. 1998 Mar. 1; p. 13.

Correspondence to: Dr. David Hammond, Department of Health Studies \& Gerontology, University of Waterloo, 200 University Ave. W, Waterloo ON N2L 3G1; fax 519 886-6424;

dhammond@uwaterloo.ca

\section{Canadian Medical Association}

\section{Special Awards - Call for Nominations}

The Canadian Medical Association invites nominations for the 2010 special awards.

- Medal of Honour

- F.N.G. Starr Award

- Medal of Service

- May Cohen Award for Women Mentors

- Sir Charles Tupper Award for Political Action

- Award for Excellence in Health Promotion

- Award for Young Leaders

- Dr. William Marsden Award in Medical Ethics

Refer to the "Awards from CMA" section on cma.ca for detailed criteria on each of the awards or contact the awards co-ordinator at $800663-7336 \times 2249$.

Nominations should be submitted in writing to:

Chair, Committee on Archives and Awards c/o Committee Co-ordinator Corporate Affairs

Canadian Medical Association

1867 Alta Vista Dr.

Ottawa ON K1G 5 W8

Closing date for receipt of nominations is Nov. 30, 2009.
Association médicale canadienne

Prix spéciaux pour l'an 2010 - Appel de candidatures
L'Association médicale canadienne sollicite des candidatures à ses prix spéciaux pour l'an 2010.

- Médaille d'honneur

- Prix F.N.G. Starr

- Médaille de service

- Prix May-Cohen pour femmes mentors

- Prix Sir-Charles-Tupper d'action politique

- Prix d'excellence en promotion de la santé

- Prix des jeunes chefs de file

- Prix Dr-William-Marsden d'éthique médicale

Voir «Prix et distinctions de l'AMC» sur le site amc.ca pour les critères détaillés de chaque prix ou contacter la coordonnatrice des prix au $800663-7336$, poste 2249.

Les candidatures doivent être soumises à la :

Présidente, Comité des archives et des distinctions a/s Coordonnatrice des comités

Affaires générale

Association médicale canadienne

1867, promenade Alta Vista

Ottawa (Ontario) K1G 5 W8

Les candidatures doivent être présentées au plus tard le 30 novembre 2009.

\section{ASSOCIATION \& CANADIAN \\ MÉDICALE \$ MEDICAL \\ CANADIENNE \& ASSOCIATION}

